\title{
Analisis Pengaruh Supply Chain Integration, Teknologi Informasi dan Inovasi Terhadap Keunggulan Bersaing Pada Perusahaan Freight Forwading
}

\author{
LISDA RAHMASARI \\ STIMART"AMNI" Semarang \\ Jl. Soekarno - Hatta No. 180 Semarang
}

Diterima 4 Januari 2019; disetujui 11 Januari 2019;

\begin{abstract}
This study aimed to find out the influence of supply chain integration, information technology and innovation on competitive advantage. The research population comprised freight forwading company in Semarang City. The sample was selected by means of the purposive sampling technique. The sample was 100 companies. The data were collected by a questionnaire, interviews, and documentation. The data analysis technique in the study was multiple regression analysis using the program of SPSS Version 17 for Windows. The results of the study showed that supply chain integration, information technology and innovation had a significant positive effect on competitive advantage. The coefficient of determination $\left(R^{2}\right)$ is 0.71 or $71 \%$, the coefficient shows that $71 \%$ of competitive advantage is affected by supply chain integration, information technology, innovation while the remaining $29 \%$ is affected by other independent variables not study.
\end{abstract}

Keywords: Supply chain integration, Information technology, Innovation, Competitive advantage and performance.

\section{PENDAHULUAN}

Latar Belakang. Asosiasi Logistik Indonesia (ALI) memperkirakan industrilogistik akan tumbuh $10 \%$ pada 2018 , salah satunya didominasi dari perdagangan elektronik atau e-commerce. Dalam sepuluh tahun terakhir bisnis logistik dalam catatan ALI selalu tumbuh pesat melampaui pertumbuhan ekonomi nasional. Persaingan e-commerce menjadi salah satu penunjang pertumbuhan bisnis logistik. Selain itu investor asing yang menanam saham juga turut andil, dimana investor asing kinibisa memiliki saham hingga 67\% (https://www.kompasiana.com).

Salah satu indikator dari kesuksesan suatu perusahaan adalah kemampuan untuk mempertahankan eksistensinya. Artinya, perusahaan perlu mempunyai nilai tambah atau kelebihan dari perusahaan-perusahaan sejenis atau pesaingnya.
Keunggulan bersaing merupakan kemampuan perusahaan dalam memenuhi harapan, keinginan, kebutuhan, pendapatan dan kemauan pengguna jasa. Apabila kondisi persaingan rendah atau bahkan tidak ada persaingan, maka produk tersebut belum dibutuhkan perusahaan. Sebaliknya, apabila tingkat persaingan semakin tinggi, maka produk tersebut menjadi semakin penting di dalam perusahaan.

Suppy chain integration menitikberatkan pada hubungan antara supplier, customer, dan perusahaan itu sendiri, harus dikelola dengan baik. untuk hal ini supplier ikut bertanggungjawab terhadap kualitas produk, hubungan yang baik dan jangka panjang dengan supplier dan customer, serta agar distribusi produk dari hulu ke hilir tepat pada waktunya sampai ke pengguna akhir (Lisda, 2011). 
Pesaing menjadikan perusahaan menggunakan teknologi informasi untuk melakukan penetrasi pasar kepada kompetitor usaha dengan cara diferensiasi produk atau jasa. Penerapan teknologi informasi dapat menjadi salah satu langkah untuk meningkatkan keunggulan bersaing. Teknologi informasi memberikan kemudahan bagi konsumen atau calon konsumen untuk dapat mengakses informasi dimanapun, kapanpun, serta keuntungan lain juga didapat ketika perusahaan dapat mengontrol apa saja perubahan atau stategi yang dilakukan pebisnis kepada perusahaannya. Teknologi informasi diperuntukkan bagi perusahaan yang melakukan pemantauan kegiatan pesaing, teknologi informasi juga dapat berfungsi sebagai tambahan informasi kepada perusahaan mengenai hal yang baik dan belum pernah dilakukan perusahaan untuk menambah daya saingnya di pasar. Hal ini juga dilakukan oleh perusahaan yang berada di negara berkembang dimana mereka menerapkan inovasi yang dilakukan oleh perusahaan dibeberapa negara maju dalam menambah nilai jual akan hasil produknya (Kaisar, 2015). Inti dari fungsi teknologi informasi adalah terciptanya efisiensi untuk mengurangi pemborosan yang dilakukan oleh perusahaan .Penerapan teknologi informasi pada akhirnya menghasilkan beberapa hasil karya yang dinikmati kemudian menghasilkan keunggulan bersaing bagi perusahaan. Keunggulan bersaing yang telah diraih perusahaan seharusnya dapat terus dipertahankan karena dengan adanya keunggulan makin banyak pesaing yang memperhatikan titik lengah perusahaan, oleh karena itu perusahaan harus terus konsisten dalam menjaga keunggulannya (Kaisar, 2015).

Keunggulan kompetitif ditunjukkan melalui inovasi yang dapat diciptakan perusahaan dengan memberikan fasilitas pelayanan yang diberikan sehingga dapat menampung segala macam keluhan atau saran yang ditujukan konsumen untuk perusahaan demi perbaikan menuju yang lebih berkualitas. Kebijakan inovasi yang baik menjadi kunci kesuksesan bagi perusahaan untuk dapat menjadi yang terdepan dengan adanya antisipasi dalam persaingan pasar (Kaisar, 2015). Kebijakan inovasi dapat memberikan layanan yang prima, meminimalisir komplain dan menjalin hubungan jangka panjang kepada pelanggan merupakan inti dalam bisnis jasa freight forwading dan menjadi tugas perusahaan untuk meningkatkan kinerja perusahaannya.

Dari latar belakang diatas untuk meningkatkan keunggulan bersaing maka peneliti melakukan penelitian yang berjudul "Analisis pengaruh Supply chain integration, teknologi informasi dan inovasi jasaterhadap keunggulan bersaing pada perusahaan freight forwading “.

\section{TINJAUAN TEORETIS}

Suppy Chain Integration. Stevens dalam penelitian Wahyu (2017) mengklasifikasikan integrasi rantai pasok kedalam tiga tingkatan, dari integrasi fungsional, integrasi internal dan integrasi eksternal. Integrasi internal didefinisikan sebagai suatu proses antar fungsional interaksi, kolaborasi, koordinasi, komunikasi dan kerjasama yang membawa bidang fungsional bersama-sama menjadi sebuah organisasi yang kohesif. Selain itu, mitra rantai pasok dapat bertukar informasi secara teratur pada instansi yang berada dalam supply chain. Supply Chain Management juga bisa diartikan jaringan organisasi yang menyangkut hubungan ke hulu (upstream) dan ke hilir (downstream), dalam proses yang berbeda dan menghasilkan nilai dalam bentuk barang/jasa di tangan pelanggan terakhir (ultimate customer/end user). Pada intinya akan memuaskan konsumen dengan bekerja sama membuat produk yang murah, mengirimkan tepat waktu dan dengan kualitas yang bagus. Supply chain yang terintegrasi akan meningkatkan keseluruhan nilai yang dihasilkan oleh supply chain tersebut. Perusahaan yang berada dalam supply chain pada intinya memuaskan konsumen dengan bekerja sama membuat produk yang murah, mengirimkan tepat waktu dan dengan kualitas yang bagus .( Lisda, 2011 ).

Indikator dari supply chain integration, meliputi :

1. Integrasi Internal

2. Integrasi Pelanggan

3. Integrasi Pemasok

Teknologi Informasi. Teknologi informasi adalah proses pertukaran data dan pesan tanpa kendala ruang dan waktu. Teknologi informasi diartikan sebagai seperangkat alat yang berbeda meliputi hardware, teori informasi, jaringan data, workstasion dan kecerdasan buatan (robotika), 
bahwa penggunaan informasi tersebut sebagai proses sistematis yang digunakan untuk melaksanakan sebuah kegiatan (Kaisar 2015). Teknologi informasi tidak hanya berhubungan dengan teknologi komputer dan bukan hanya untuk mengolah data atau memperoleh informasi, tetapi juga untuk memperbaiki cara berkomunikasi. Teknologi informasi juga dapat didefinisikan sebagai bentuk teknologi yang dibuat meliputi segala bentuk teknologi yang terlibat dalam menangkap, memanipulasi, berkomunikasi, menyajikan dan menggunakan data. Oleh karena itu teknologi informasi menyangkut segalanya mengenai hardware ataupun software, perangkat peripheral yang melekat pada computer, perangkat komunikasi, jaringan yang menghubungkan internet dan fotocopy, mesin faksimili, telpon seluler, terkait perangkat nirkabel yang dikendalikan mesin pabrik, robot, dan perekam video, (Anisa, 2015). Teknologi informasi juga dapat didefinisikan sebagai perangkat atau proses yang memediasi atau menjembatani komunikasi orang yang satu ke orang yang lainya sehingga segala bentuk komunikasi yang ada dapat tersampaikan dengan baik. Bidang teknologi informasi meliputi berbagai metode dan alat termasuk analisis sistem dan desain metodologi, alat pemrograman dan metodologi, perangkat keras komputer, perangkat lunak computer, teknologi penyimpanan, teknologi informasi, dan sistem informasi yang terintegrasi dimana mengabungkan semua elemen yang tersebut diatas kedalam suatu sistem. Oleh karena itu teknologi informasi alat yang terbaik dalam mendeteksi masalah-masalah yang terjadi di masyarakat (Kaisar, 2015). Indikator dari teknologi antara lain kecanggihan, kemanfaatan dan efektivitas.
Inovasi. Inovasi secara konvensional sebagai suatu terobosan yang berhubungan dengan produkproduk baru. Inovasi didefinisikan bahwa inovasi adalah konsep yang lebih luas yang menjelaskan tentang penerapan gagasan, produk, atau proses yang baru. Inovasi merupakan mekanisme perusahaan untuk beradaptasi dalam lingkungan yang dinamis, oleh karena itu perusahaan dituntut untuk mampu menciptakan pemikiran baru, gagasan baru dan menawarkan produk yang inovatif serta peningkatan pelayanan yang memuaskan pelanggan (Kusumo, 2006). Inovasiadalah pengenalan sesuatu hal yang baru sebagai wujud keberhasilan suatu hal yang baru tersebut yang menjadikan sesuatu menjadi lebih bermanfaat. Inovasi juga dapat dinyatakan sebagai perwujudan, kombinasi, atau sintesis ilmu pengetahuan yang asli, relevan, produk yang bernilai baru, sebuah proses, atau jasa. Inovasi juga melibatkan kreativitas, namun keduanya tidak identik. Inovasi melibatkan tindakan atau gagasan kreatif untuk membuat beberapa perbedaan secara spesifik dan nyata dalam domain dimana inovasi dibuat. Inovasi juga memuat transformasi suatu ilmu pengetahuan menjadi produk yang baru, yang bisa diproses juga dalam bentuk jasa guna memenuhi kebutuhan dari pelanggan. Inovasi juga meliputi proses teknis, fisik, dan pengetahuan yang bertujuan utama untuk mengembangkan produk. Sedangkan inovasi bermanfaat dalam perusahaan untuk menciptakan nilai proposisi baru melalui rangkaian kegiatan seperti menawarkan produk atau jasa baru, mengadopsi praktek organisasi dan operasional baru, memberi solusi terhadap teknologi atau menciptakan keterampilan baru dan kompetensi, inovasi juga dapat mendorong keterampilan dan pengetahuan yang diperlukan untuk secara efektif

\section{Gambar 1}

\section{Kerangka Penelitian Pengaruh Karakteristik Individu, Karakteristik Pekerjaan Dan Karakteristik Lingkungan Terhadap Motivasi Kerja Pegawai Pada Satuan Polisi Pamong Praja Kota Pontianak}

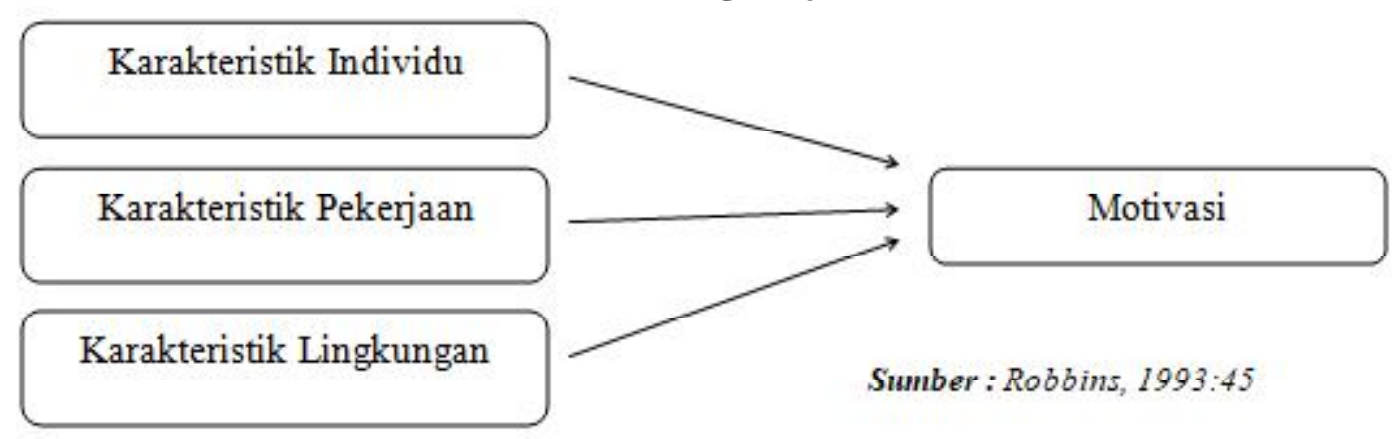


mewujudkan, menguasai dan meningkatkan teknologi yang sudah ada, dan untuk menciptakan sesuatu yang baru (Kusumo, 2006). Inovasi adalah proses menciptakan produk komersial dari suatu penemuan. Manfaat dari suatu inovasi yang paling khas adalah memberikan pengetahuan, membangun suatu merek, membangun suatu wadah baru dalam bentuk komunitas yang baru, dan membuat suatu budaya baru. Alasan beberapa perusahaan melakukan sebuah inovasi adalah inovasi membuat keuntungan bagi perusahaan, inovasi yang menghasikan produk atau jasa dengan biaya rendah atau inovasi yang memberikan diferensiasi pada produk sehingga memberikan harga yang lebih untuk tambahan biaya diferensiasi tersebut. Kesuksesan inovasi terjadi jika produk diterima dan menghasilkan keuntungan bagi perusahaan. Sedangkan proses inovasi dapat dilihat ketika rangkaian adopsi dari suatu hal yang sudah ada kemudian dilakukan diferensiasi sehingga tercipta hal yang lebih baru yang nilai dan manfaatnya dirasakan lebih. Indikator dari inovasi adalah inovasi proses, inovasi pasar dan inovasi teknis :

1. Keunggulan bersaing-Perusahaan harus mempunyai kemampuan bersaing dengan memanfaatkan kemampuan untuk menangani masalah atau kasus tertentu sebagai kemampuan tumbuh dari waktu ke waktu, untuk memanfaatkan dan menciptakan sumber daya baru, seperti keterampilan (melalui teknologi baru atau aplikasi perangkat lunak), dan untuk membuka peluang baru untuk pengembangan jenis baru produk. Sebuah perusahaan dikatakan mempunyai keuntungan kompetitif jika perusahaan melaksanakan strategi penciptaan nilai yang pada prosesnya akan menghasilkan tenaga-tenaga profesional. Akhirnya, hasil kinerja yang unggul dan keunggulan dalam produksi mencerminkan keunggulan kompetitif. Keunggulan kompetitif merupakan keuntungan lebih dari pesaing yang diperoleh dengan menawarkan konsumen nilai yang lebih besar, baik dengan cara harga yang lebih rendah atau dengan memberikan manfaat yang lebih besar dan layanan yang membenarkan harga yang lebih tinggi, Porter (2001).

2. Keunggulan kompetitifmempunyai tiga dimensi yaitu biaya, diferensiasi dan fokus dengan pesaing. Porter menunjukkan bahwa diferensiasi menghasilkan sebuah biaya lebih rendah dibandingkan dengan pesaing. Strategi diferensiasi adalah satu cara untuk meraih keunggulan kompetitif. Biasanya, hal ini berasal dari organisasi skala besar mengembangkan efisiensi mereka karena pengalaman berulang mereka dari proyek yang dikerjakan atau menggunakan kekuasaan mereka untuk meningkatkan biaya yang lebih rendah. Indikator dari keunggulan bersaing adalah keunggulan harga, keunggulan produk dan keunggulan layanan.

Hipotesis. Hipotesis merupakan jawaban sementara terhadap rumusan masalah penelitian yang bertujuan mengarahkan dan memberikan pedoman dalam pokok permasalahan serta tujuan penelitian. Maka dari uraian masalah yang ada, dapat dimunculkan suatu hipotesis penelitian sebagai berikut :

H1 : Supply Chain Integration berpengaruh positif dan signifikan terhadap keunggulan bersaing

$\mathrm{H} 2$ : Teknologi Informasi berpengaruh positif dan signifikan terhadap keunggulan bersaing.

H3 : Inovasi berpengaruh positif dan signifikan terhadap keunggulan bersaing.

\section{METODE PENELITIAN}

Jenis dan Sumber Data. Jenis dan sumber data yang digunakan dalam penelitian ini adalah data primer, yaitu data yang diperoleh langsung di lapangan baik melalui wawancara dengan pihak terkait, kuisioner, dan observasi langsung, serta data sekunder, yaitu data yang telah diolah dan diperoleh dari perusahaan maupun pihak-pihak terkait.

Metode Pengumpulan Data. Data yang dikumpulkan dalam penelitian ini, dilakukan menggunakan teknik :

- Wawancara bebas yaitu teknik untuk memperoleh informasi dan melengkapi data dengan mewawancarai pihak-pihak terkait, baik itu pihak pemerintah, swasta, dan masyarakat.

- Observasi yaitu teknik yang digunakan untuk melengkapi data dengan melihat dan mencermati secara langsung ke obyek yang akan diteliti.

- Metode dokumentasi yaitu teknik dengan menelaah dokumen-dokumen dan laporanlaporan yaitu data sekunder yang berhubungan 
dengan tujuan penelitian.

- Kuisioner merupakan teknik mengumpulkan data dengan memberikan beberapa pertanyaan kepada setiap responden berdasarkan data-data yang dibutuhkan dalam penelitian.

Populasi dan sampel. Populasi dari penelitian ini adalah Perusahaan Freight Forwading di Semarang . Sedangkan sampel yang akan diambil dalam penelitian ini hanyalah 100 perusahaan yang dianggap telah mewakili dari keseluruhan populasi.

\section{HASIL DAN PEMBAHASAN}

Uji Validitas dan Reliabilitas. Dari hasil uji validitas, semua item pertanyaan memiliki nilai korelasi positif dan lebih besar dari 0,6. Hal ini berarti bahwa semua instrumen dalam penelitian ini adalah valid. Begitu pula, hasil uji reliabilitas menunjukkan semua variabel memiliki nilai koefisien Alpha Chronbach lebih besar dari 0,6, yang artinya bahwa seluruh instrumen yang digunakan dalam penelitian ini adalah reliabel.

Uji Asumsi Klasik. Sebelum dilakukan uji regresi linear berganda maka dilakukan uji asumsi klasik, dari hasil uji multikolerianitas menunjukkan bahwa tidak ada nilai VIF yang lebih dari 10 sehingga dapat dikatakan bahwa tidak ada korelasi antara variabel bebas. Selanjutnya nilai signifikansi tiap variabel terhadap absolute residual lebih dari 0,05 , artinya persamaan regresi mengalami homokedastisitas (tidak mengandung Heterokedastisitas) dan untuk uji normalitas data penelitian ini berdistribusi normal, dikarenakan nilai $\alpha$ lebih besar dari 0,05 .

Analisis Regresi Berganda. Analisis regresi berganda dilakukan meliputi variabel bebas supply chain integration $\left(\mathrm{X}_{1}\right)$, penerapan teknologi informasi $\left(\mathrm{X}_{2}\right)$, inovasi $\left(\mathrm{X}_{3}\right)$, dan variabel terikat keunggulan bersaing $(\mathrm{Y})$. Berikut adalah hasilnya pada Tabel 1.

Berdasarkan hasil perhitungan diatas maka dapat dijelaskan melalui persamaan regresi sebagai berikut :

$\mathrm{Y}_{1}=15.504+0.558 \mathrm{X}_{1}+0,440 \mathrm{X}_{2}+0,200 \mathrm{X}_{3}+\mathrm{e}$

Dari perhitungan beta coefficient menunjukkan bahwa dari ketiga variabel tersebut dapat diurutkan dari yang paling berpengaruh terhadap variabel dependen keunggulan bersaing pada perusahaan freight forwading (Y) yaitu supply chain integration $\left(\mathrm{X}_{1}\right)$, penerapan teknologi informasi $\left(\mathrm{X}_{2}\right)$, inovasi $\left(\mathrm{X}_{3}\right)$. Nilai pada ketiga variabel bertanda positif sehingga dapat dikatakan bahwa ketiga faktor tersebut berpengaruh positif terhadap keunggulan bersaing pada perusahaan freight forwading. Dari hasil penelitian ini nilai koefisien determinasi $\left(\mathrm{R}^{2}\right)$ sebesar $71 \%$, nilai tersebut menunjukkan bahwa $71 \%$ keunggulan bersaing dipengaruhi oleh supply chain integration, teknologi informasi dan inovasi sedangkan sisanya $29 \%$ dipengaruhi oleh variabel bebas lain yang tidak diteliti.

\section{SIMPULAN}

Berdasarkan hasil pengujian statistik dan pembahasan yang di ada pada bab sebelumnya dapat diambil beberapa kesimpulan sebagai berikut :

1. Supply Chain Integration berpengaruh positif dan signifikan terhadap keunggulan bersaing sebesar 0.508 dengan tingkat signifikansi sebesar $0.000<0.05$ yang artinya apabila ada peningkatan Supply Chain Integration maka

Table 1

Hasil Uji Regresi Linier Berganda 1 Coefficients ${ }^{\mathrm{a}}$

\begin{tabular}{|c|c|c|c|c|c|c|c|}
\hline \multirow[t]{2}{*}{ Model } & \multicolumn{2}{|c|}{ Unstandardized Coefficients } & \multirow{2}{*}{$\frac{\text { Standardized Coefficients }}{\text { Beta }}$} & \multirow[t]{2}{*}{$\mathrm{t}$} & \multirow[t]{2}{*}{ Sig. } & \multicolumn{2}{|c|}{ Collinearity Statistics } \\
\hline & B & Std. Error & & & & Tolerance & VIF \\
\hline 1 (Constant) & 15.504 & .858 & & 29.797 & .000 & & \\
\hline SCI & .508 & .099 & .566 & 3.899 & .000 & .120 & 5.566 \\
\hline Penerapan TI & .440 & .098 & .469 & 3.483 & .001 & .181 & 5.524 \\
\hline Inovasi Jasa & .200 & .131 & .411 & 4.050 & .060 & .181 & 5.524 \\
\hline
\end{tabular}

a. Dependent Variable: Keunggulan Bersaing

a. Dependent Variable: Keunggulan Bersaing 
keunggulan bersaing akan meningkat. Dengan demikian hipotesis yang mengatakan ada pengaruh Integration terhadap keunggulan bersaing dinyatakan dapat diterima.

2. Penerapan teknologi informasi berpengaruh positif dan signifikan terhadap keunggulan bersaing sebesar 0.440 dengan tingkat signifikansi sebesar $0.001<0.05$ yang artinya apabila ada peningkatan penerapan teknologi informasi maka keunggulan bersaing akan meningkat. Dengan demikian hipotesis yang mengatakan ada pengaruh penerapan teknologi informasi terhadap keunggulan bersaing dinyatakan dapat diterima.

3. Inovasi berpengaruh positif tetapi tidak signifikan terhadap keunggulan bersaing dengan koefisien regresi sebesar 0.200 dan tingkat signifikansi sebesar $0.06>0.05$. Dengan demikian hipotesis yang menyatakan ada pengaruh inovasi jasa terhadap keunggulan bersaing dinyatakan ditolak.

\section{DAFTAR PUSTAKA}

Aldhilla, Mochamad Ridho. 2014. Pengaruh Point of Purchase Communication Terhadap Impulse Buying (Studi pada Konsumen Hipermarket Lotte Mart Kota Bandung). Skripsi. Universitas Pendidikan Indonesia

Anisa, 2015, Pengaruh Point Of Purchase, Discount Dan Store Atmosphere Terhadap Impulse Buying Konsumen, https://media.neliti.com/ media/publications/101227

Basu Swastha dan T. Hani Handoko, 2000, Manajemen Pemasaran (Analisa. Perilaku Konsumen), Yogyakarta : BPFE UGM

Ella, 2015 ,Pengaruh Kualitas Layanan Dan Inovasi Layananterhadap Kepuasan Konsumen Pada Rumah Sakit Buah Hati Di Kabupaten Kudus, Skripsi Jurusan Manajemen Fakultas Ekonomi UNIVERSITAS NEGERI Semarang
Ghozali, Imam. 2011. Aplikasi Analisis Multivariate Dengan Program IBM SPSS 19. Semarang: Universitas Diponegoro. Habibi, Maksum dan Gunadi.2013.Pengantar Ekonomi dan Bisnis, Bidang Keahlian Bisnis dan Manajemen SMK Kelas X.Jakarta.

Hatane, Semuel. 2006. Dampak Respon Emosi Terhadap Kecenderungan Perilaku Pembelian Impulsif Konsumen Online dengan Sumberdaya yang Dikeluarkan dan Orientasi Belanja sebagai Variabel mediasi. Jurnal Manajemen dan Kewirausahaan. Vol. 8. No. 2

Kusumo, Agung R.W. 2006. Analisis Faktor-Faktor Yang Mempengaruhi Inovasi Produk Untuk Meningkatkan Keunggulan Bersaing Dan Kinerja Pemasaran (Studi pada Industri Batik Skala Besar dan Sedang Di Kota dan Kabupaten Pekalongan). Universitas Diponegoro, Semarang Jawa Tengah. (Online), diakses 12 Oktober 2011

Kaisar, 2015, Analisis Pengaruh Teknologi Informasi Dan Inovasi Terhadap Keunggulan Bersaing Untuk Meningkatkan Kinerja Organisasi, Jurusan Manajemen Fakultas Ekonomika dan Bisnis Universitas Diponegoro

Lisda, 2011 ,Pengaruh Supply Chain Management Terhadap Kinerja perusahaan dan Keunggulan Bersaing Majalah Ilmiah Informatika.

Mellisa, 2015, Efektivitas Point Of Purchase Dalam Meningkatkan Impulse Buying Pada Peritel Di Surabaya, http://download.portalgaruda.org.

Novikristiadi, 2018, Pertumbuhan Bisnis Logistik di Indonesia Diprediksi Meningkat 10\% di 2018, https://www.kompasiana.com

Regina Suharto dan Devie. 2013. "Analisa Pengaruh Supply Chain Management terhadap Keunggulan Bersaing dan Kinerja Perusahaan”. Jurnal Business Accounting Review.Vol.1, No. 2, (2013)

Wahyu, 2017 Integrasi Rantai Pasok Terhadap Kinerja Dan Daya Saing Kakao, Jurnal Bisnis Darmajaya, Vol.03. No.02, Juli 2017

Yas, 2013, Industri Logistik Indonesia Diprediksi Capai Rp 1,63 triliun, www.liputan6.com 